\title{
ANALISIS POTENSI BAHAYA LEDAKAN SPPBE DI SE KITAR CALON TAPAK RDE
}

\section{ANALYSIS OF THE POTENTIAL EXPLOSION HAZARD SPPBE AROUND THE CANDIDATE SITE RDE}

\author{
Siti Alimah, Dedy Priambodo, J une Mellawati
}

Pusat Kajian Sistem Energi Nuklir- BATAN

Jl. Kuningan Barat, Mampang Prapatan; Jakarta 12710, Telp/ Fax : (021) 5204243

E-mail : alimahs@batan.go.id dedypriambodo@batan.go.id june_mellawati@batan.go.id

\begin{abstract}
Abstrak
Potensi bahaya eksternal akibat ulah manusia terhadap tapak RDE (Reaktor Daya Eksperimental) harus diidentifikasi dan dianalisis untuk memperoleh basis desain yang cocok dengan instalasi yang akan dibangundi lokasi tapak tersebut. Salah satu sumber bahaya eksternal tersebut adalah keberadaan depo penyimpanan bahan bakar gas (SPPBE) yang merupakan salah satu sumber tidak bergerak. Bahaya ledakan dari SPPBE berpotensi membahayakan tapak jika tapak RDE berada dalam SDV (Screening Distance Value) SPPBE tersebut ( 5 $\mathrm{km}$ ), sehingga diperlukan analisis potensi bahaya ledakan. Tujuan penelitian ini adalah untuk mengetahui sejauh mana potensi bahaya ledakan yang ditimbulkan SPPBE yang berada di sekitar area tapak RDE, jika terjadi kebocoran tangki SPPBE. Metode penelitian meliputi pengumpulan data primer dan konfirmasi di lapangan sekitar area tapak, pemetaan, serta melakukan analisis potensi bahaya ledakan menggunakan software ALOHA versi 5.4.5 dan MARPLOT. Hasil konfirmasi di lapangan menunjukkan bahwa tapak RDE berada dalam SDV dua buah SPPBE karena berjarak 2,995 dan 4,141 km dari area tapak. Hasil analisis menunjukkan bahwa lepasan gas elpiji dari kedua SPPBE tidak membahayakan tapak RDE karena ledakannya tidak mencapai area tapak dan tidak menimbulkan kerusakan bangunan, dengan asumsi kebocoran terjadi di bagian bawah tanki sebesar 2,5 inchi.
\end{abstract}

Kata Kunci : ledakan, SPPBE, tapak RDE, SDV.

\begin{abstract}
Potential of external hazards cause of human induced event to RDE (Experimental Power Reactor) must be identified and analyzed to obtain suitable design basis with installation will be built. One source of external hazards is existing of a gaseous fuel storage depot (SPPBE), which is one of the stationary sources. Explosion hazards from SPPBE have potential harmfull of RDE site if the site is within the SPPBE-SDV (Screening Distance Value) $(5 \mathrm{~km})$ so that the required analysis of the potential explosion hazards. The purpose of this research was to determine the extent of the potential hazard explosion of SPPBE around of RDE site area, if happen leakage of the SPPBE tank. The research method involves collecting data, a confirmation around the site area, mapping and analysis of the potential hazards of explosion using ALOHA software version 5.4.5 and MARPLOT. Confirmation results show that there are two SPPBE around the site are with distances 2.995 and $4.141 \mathrm{~km}$. The analysis showed that the releases of LPG from both SPPBE not endanger tread RDE because the explosion did not reach the site area and does not cause damage to the building, assuming a leak occurs in the bottom of the tank by 2.5 inch.
\end{abstract}

Keywords : explosion, SPPBE, site RDE, SDV. 
Diterima (received) : 28 Mei 2016, Direvisi (reviewed) : 10 Juni 2016, Disetujui (accepted) : 20 Juni 2016

\section{PENDAHULUAN}

BATAN sebagai lembaga litbang di bidang nuklir berencana membangun Reaktor Daya Eksperimental (RDE) di kawasan Puspiptek Serpong, untuk mendukung kebijakan pemerintah di bidang energi. RDE tersebut direncanakan untuk demonstrasi pembangkitan listrik dan aplikasi panas proses untuk industri. Terkait persiapan pembangunan RDE, dan sesuai peraturan Kepala Badan Pengawas Tenaga Nuklir Nomor 6 Tahun 2008 tentang evaluasi tapak reaktor daya, maka aspek kejadian eksternal akibat ulah manusia harus dikaji dan dievaluasi[1].

Sumber kejadian eksternal akibat ulah manusia dapat diklasifikasikan sebagai sumber bergerak dan tidak bergerak. Sumber tidak bergerak meliputi kegiatan manusia terkait kilang minyak, industri kimia, depo penyimpanan BBM (SPBU), depo penyimpanan gas (SPPBE), jaringan transmisi penyiaran dan telekomunikasi, penambangan/penggalian, keberadaan hutan, fasilitas nuklir lain, peralatan berputar dengan energi tinggi, dan fasilitas militer. Sedangkan sumber bergerak meliputi kegiatan manusia terkait keberadaan jalur rel kereta api, Ialulintas jalan raya, kapal, jalur pipa (gas/minyak), bandar udara (pergerakan pesawat dan frekuensi penerbangan), koridor lalu lintas udara dan jalur penerbangan (militer/sipil)[1,2,3].

Tujuan penelitian adalah melakukananalisis potensi bahaya ledakan depo penyimpanan bahan bakar gas (SPPBE) terhadap tapak RDE, jika terjadi kebocoran tangki di SPPBE.

\section{BAHAN DAN METODE}

\section{Metode}

Metode yang digunakan dalam penelitian adalah :

1. Pengumpulan data keberadaan SPPBE di sekitar area tapak (hingga radius $5 \mathrm{~km}$ ) dan konfirmasi kapasitas SPPBE tersebuat.

2. Pemetaan lokasi SPPBE dan SDV SPPBE.

3. Analisis potensi bahaya lepasan gas, kebakaran dan ledakan dengan menggunakan software ALOHA versi 5.4.5, Juli 2015 dan MARPLOT.

\section{KARAKTER ISTIKA LPG}

Stasiun Pengisian dan Pengangkutan Bulk Elpiji (SPPBE) merupakan stasiun yang melayani pengangkutan dan pengisian gas LPG (Liquified Petroleum Gas) Pertamina dengan merek dagang ELPIJI. Salah satu potensi bahaya yang mungkin ditimbulkan oleh kegiatan SPPBE adalah bahaya ledakan. Hal ini karena gas tersebut termasuk kategori gas yang pada temperatur ambien sifat volatile (mudah menguap) dan flammable (mudah terbakar) yang tinggi (batas flammable terendah 1,8-1,9\%) dan dapat meledak jika bercampur udara atau oksigen pada kandungan uap 2-10\% volume, tidak berwarna, tidak korosif dan tidak berbau. Titik didih -40 sampai $80^{\circ} \mathrm{C}$, titik nyala $-104^{\circ} \mathrm{C}$, autoignition $450^{\circ} \mathrm{C}$. Sejumlah kecil pembau digunakan untuk deteksi kebocoran[4,5]. Komersial LPG yang ada di pasaran, terdiri dari $30 \%$ propana $\left(\mathrm{C}_{3} \mathrm{H}_{8}\right)$ dan $70 \%$ butana $\left(\mathrm{C}_{4} \mathrm{H}_{10}\right)$, serta menggunakan tekanan uap sekitar tekanan uap sekitar 100 psig[5]. Pada temperatur $25^{\circ} \mathrm{C}$, tekanan uap adalah 3,6 barg[6]. Kebakaran terjadi jika terdapat 3 unsur yaitu adanya bahan bakar, oksigen dan sumber panas seperti loncatan bunga api atau pemantik[7]. LPG ditrasportasi dan disimpan dalam fase cair pada tekanan cukup tinggi.

Gas campuran butana dan propana tersebut mempunyai densitas 1,859[8], sehingga jika terjadi kebocoran gas akan sangat berbahaya, jika tidak ada angin yang menghembusnya ke udara terbuka. Oleh karena itu sangat penting mempertimbangkan persyaratan ventilasi. Ventilasi harus cukup ketika terdapat kejadian kebocoran. Gas LPG lebih berat dari udara, dan mengalir turun sampai level terendah dan dapat terakumulasi untuk jangka waktu yang lama, sehingga dapat menimbulkan bahaya ledakan ${ }^{[9]}$.

Pada pelepasan gas kondisi atmosfer, gas akan naik atau turun, tergantung kepadatan uap dan akan diarahkan sesuai jalur angin. Pada ketiadaan angin, gas yang lebih berat akan berkumpul dititik bawah medan. Pelepasan gas tersebut, jika terignisi akan terbakar. Pelepasan gas dalam jumlah besar dapat menimbulkan bahaya yang signifikan bagi lingkungan karena selain menghasilkan kebakaran juga ledakan.

Ledakan campuran gas LPG-udara diruang yang terkungkung adalah berbahaya, karena tekanan tinggi dan laju peningkatan tekanan yang tinggi dicapai 
lebih cepat setelah ignisi. Hal ini sama dengan proses yang membahayakan bejana tanpa peralatan penekan ledakan. Ledakan didefinisikan sebagai suatu kejadian yang mengarah pada kenaikan tekanan secara cepat ${ }^{[10]}$. Ledakan dapat terjadi dibagian dalam proses atau perpipaan, dalam bangunan atau lepas pantai, dan juga dapat terjadi di area terbuka. Fenomena lepasan gas atau uap cairan mudah terbakar terlepas ke atmosfer diperlihatkan dalam Gambar 1. Jika awan uap yang dibentuk dari pelepasan tersebut tidak dalam batas flammability atau jika sumber ignisi lemah, awan gas akan diencerkan dan menghilang. Ignisi dapat terjadi segera atau tertunda sampai beberapa menit, yang semuanya tergantung circumstances. Dalam kasus ignisi segera (sebelum bercampur dengan udara atau adanya oksigen), kebakaran akan terjadi.

Situasi yang paling berbahaya akan terjadi jika sejumlah besar awan campuran bahan bakar-udara yang mudah terbakar terbentuk dan menyala[5]. Waktu dari saat pelepasan sampai ignisi beberapa detik sampai beberapa menit. Tekanan yang dihasilkan gelombang kebakaran akan tergantung pada seberapa cepat api disebarkan dan bagaimana tekanan dapat terekspansi dari awan uap (diatur pengungkung). Jadi faktor yang mempengaruhi secara substansial dari kejadian kecelakaan adalah waktu penyalaan dalam menghasilkan awan dan tingkat pengungkungan yang diberikan lingkungan sekitarnya ${ }^{[11]}$ Akibat dari ledakan gas dapat tidak membahayakan sampai pengrusakan total. Tekanan akibat ledakan gas dapat membahayakan personil dan material atau dapat menyebabkan kebakaran dan bleve. Kebakaran adalah kejadian sangat umum setelah ledakan gas. Ketika awan uap ternyalakan, api dapat menyebar dalam dua mode yang berbeda yaitu deflagrasi dan detonasi.

Mode deflagrasi adalah perambatan api yang paling umum. Perambatan deflagrasi pada kecepatan subsonic $(1-1000 \mathrm{~m} / \mathrm{det})$. Tekanan ledakan dapat mencapai berberapa barg, tergantung kecepatan kebakaran. Detonasi adalah reaksi kejutan dimana api bergerak dengan kecepatan supersonic (lebih cepat dari kecepatan suara), dengan kecepatan 1500-2000m/det dan tekanan puncak 15-20 bar. Detonasi menghasilkan tekanan jauh lebih tinggi dari yang dianggap ledakan biasa[7,11]. Jika tekanan awal tinggi maka tekanan detonasi akan lebih parah dan merusak.

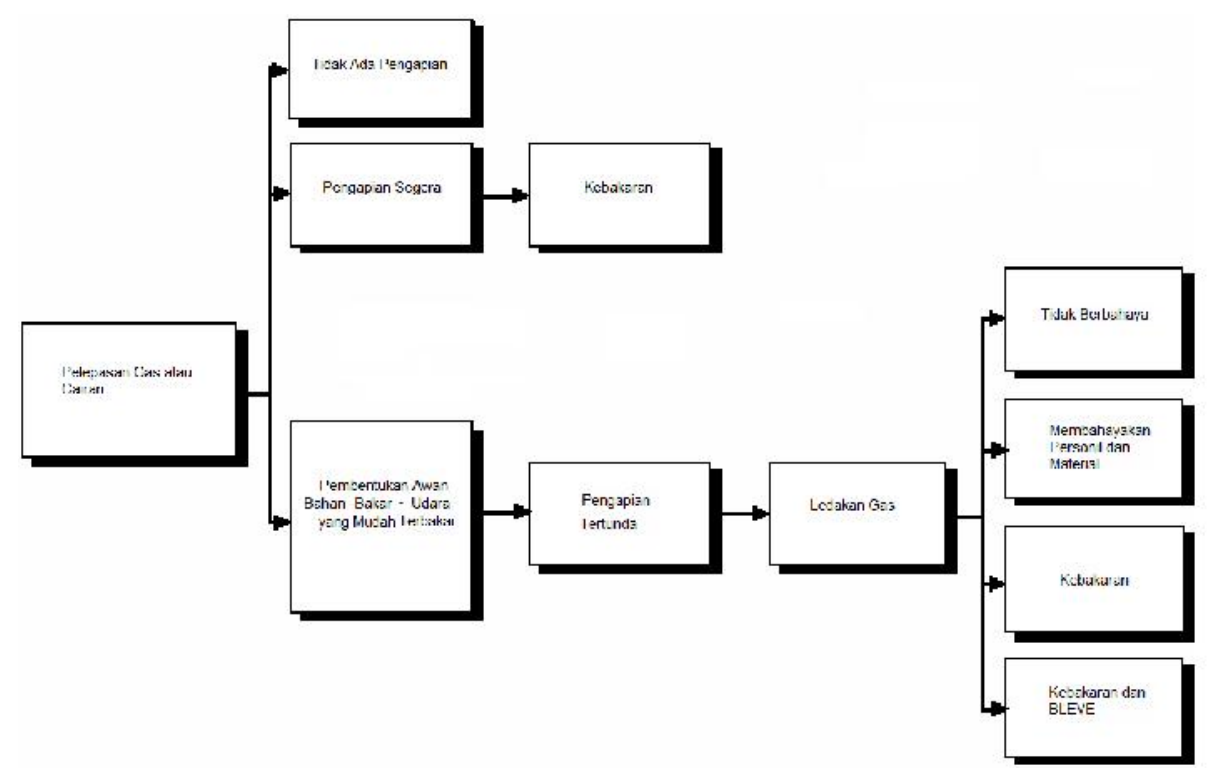

Gambar 1.

Pohon Kejadian Konsekuensi Pelepasan Gas atau Uap cairan yang Mudah Terbakar terlepas ke Atmosfer ${ }^{[5,12]}$

\section{HASIL DAN PEMBAHASAN}

Berdasarkan konfirmasi di lapangan diperoleh data adanya 2 buah SPPBE yang merupakan depo penyimpanan dan penyaluran LPG, yaitu berada di Taman Tekno Ciater, Tangerang Selatan dengan kapasitas gas masing-masing 15000 kg (sebanyak 2 tanki) dan $30000 \mathrm{~kg}$. 
Screening Distance Value (SDV) yang merupakan penentuan nilai jarak penapisan, untuk SPPBE adalah $5 \mathrm{~km}^{[1]}$. Hasil penapisan diketahui bahwa tapak berada di dalam SDV ke dua industri gas (SPPBE) yaitu PT. BM berjarak 2,995 km dan PT. ISR berjarak 4,141 km masing-masing dari tapak (di dalam SDV) dan ditunjukkan pada Gambar 1, sehingga dilakukan analisis.

Salah satu analisis potensi bahaya yang mungkin ditimbulkan oleh SPPBE adalah ledakan. Analisis dimaksudkan untuk mengetahui dampak dari suatu kejadian kecelakaan karena kegiatan manusia disekitar tapak berpotensi menimbulkan bahaya keamanan dan keselamatan tapak. Analisis dilakukan dengan menggunakan software ALOHA (Areal Locations of Hazardous Atmospheres) versi 5.4.5 dan MARPLOT (dari Badan Perlindungan Lingkungan Amerika Serikat/US EPA Amerika).

Langkah awal pada analisis adalah mengidentifikasi jenis dan jumlah inventori maksimum fluida dalam fasilitas, spesifikasi tempat penyimpanan dan data meteorologi disekitar lokasi. Data meteorologi stasiun terdekat dari tapak menunjukkan bahwa kecepatan angin 9,8 m/det, arah angin $150^{\circ}$, temperatur $34,1^{\circ} \mathrm{C}$ dan kelembaban $74,6 \%[13]$.

Data masukan untuk analisis diperlihatkan dalam Tabel 1.

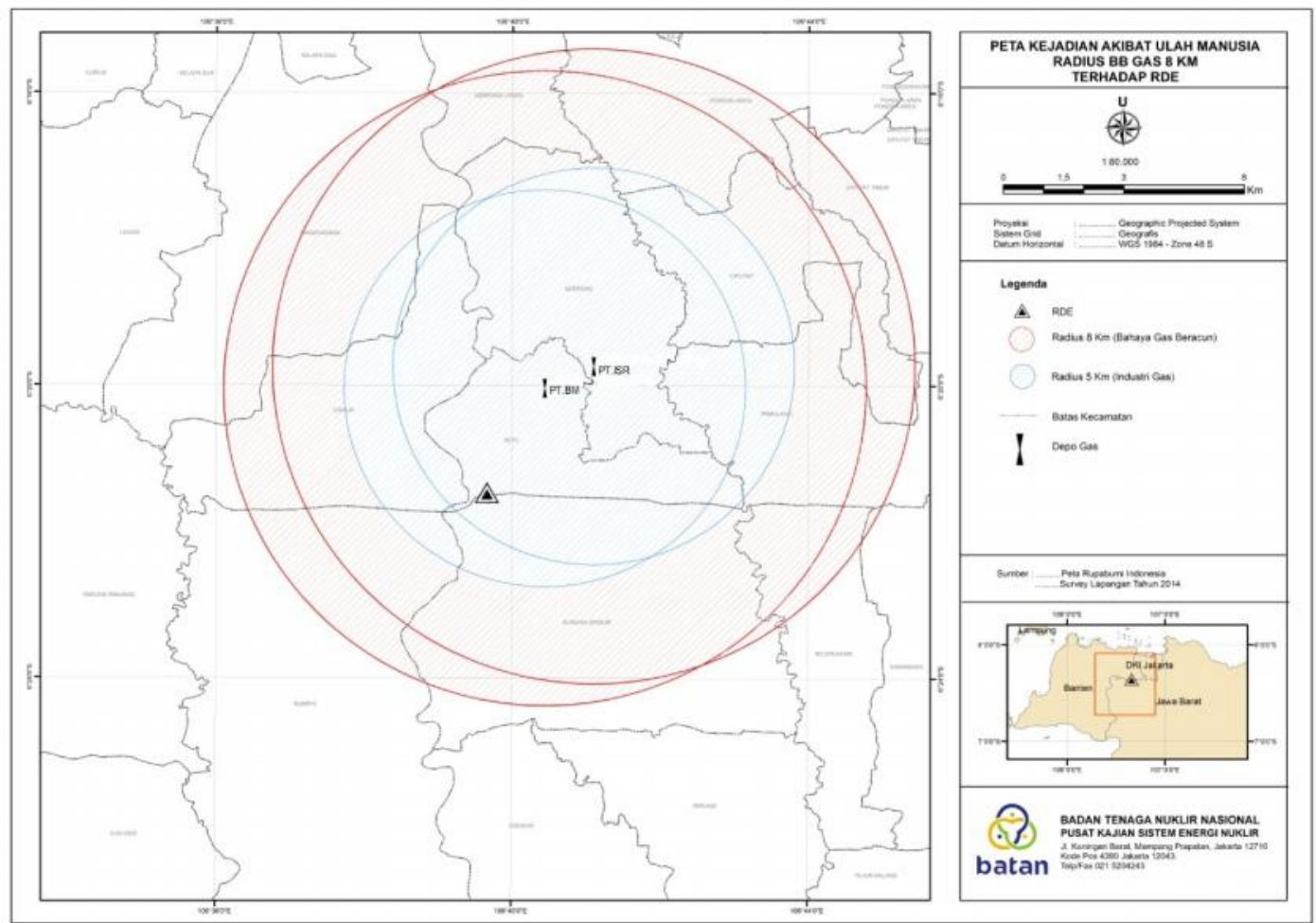

Gambar 2.

SDV SPPBE terhadap Tapak RDE[13]

Tabel 1.

Data Masukan Untuk Analisis

\begin{tabular}{|c|c|c|c|c|c|c|}
\hline \multirow[b]{2}{*}{ Sumber } & \multirow[b]{2}{*}{$\begin{array}{c}\text { Jenis } \\
\text { bahan }\end{array}$} & \multirow[b]{2}{*}{$\begin{array}{l}\text { Komponen } \\
\text { utama }\end{array}$} & \multirow[b]{2}{*}{ Komponen } & \multicolumn{2}{|c|}{ Dimensi Tanki } & \multirow[b]{2}{*}{$\begin{array}{l}\text { Kapasitas } \\
\text { (Ton) }\end{array}$} \\
\hline & & & & $\begin{array}{c}\text { Diameter } \\
\text { dalam }(\mathrm{mm})\end{array}$ & $\begin{array}{c}\text { Panjang } \\
\text { (mm) }\end{array}$ & \\
\hline PT. BM & LPG & Butana & Skid Tank & 2100 & 8668 & 15 \\
\hline PT. ISR & LPG & Butana & Storage Tank & 2890 & 11070 & 30 \\
\hline
\end{tabular}

Lepasan gas pada tangki LPG milik PT. BM berasal dari skid tank, sedangkan PT. ISR berasal dari storage tank. Diasumsikan bahwa truk tanki mengalami kebocoran pada bagian katup transfer dibagian bawah tanki sebesar 2,5 inchi. Dengan data masukan analisis untuk ALOHA ${ }^{[14]}$ seperti terlihat dalam Tabel 1, diperoleh skenario terjadinya lepasan gas sebagai berikut:

- Akibat kebocoran, senyawa butana keluar 
dari tanki PT. BM dengan laju alir rata-rata $231 \mathrm{~kg} / \mathrm{menit}$, dan lepasan gas sebanyak $12.554 \mathrm{~kg}$ selama 1 jam. Hal yang sama terjadi pada PT. ISR dan diperoleh laju alir rata-rata lepasan gas sebanyak 236 $\mathrm{kg} / \mathrm{menit}$, dan lepasannya sebanyak $13.811 \mathrm{~kg}$ selama 1 jam.

- Kejadian ledakan dapat diuraikan sebagai berikut :

- Mula-mula terjadi kebocoran gas butana pada skid tank PT. BM (kapasitas $15000 \mathrm{~kg}$ ) dengan laju kebocoran rata-rata $231 \mathrm{~kg} /$ menit dan melepaskan gas sebanyak 12554 $\mathrm{kg} / \mathrm{jam}$ sehingga membentuk "awan uap" (campuran 2 fasa : gas \& aerosol butana).

- Demikian pula kebocoran gas butana pada storage tank PT. ISR (kapasitas $30000 \mathrm{~kg}$ ) dengan laju kebocoran ratarata $236 \mathrm{~kg} /$ menit dan melepaskan gas sebanyak $13811 \mathrm{~kg} / \mathrm{jam}$ sehingga membentuk "awan uap" (campuran 2 fasa: gas \& aerosol butana).

- Selanjutnya awan uap terperangkap diantara perpipaan pada instalasi pengisian tabung LPG dan ternyalakan oleh percikan api sehingga terjadi nyala dan menyebabkan ledakan.

- Ledakan yang terjadi merupakan jenis vapor cloud explosion yang mempunyai daya rusak.

- Ledakan yang disebabkan oleh campuran gas dapat merusak bangunan, menyebabkan luka pada pekerja/pengunjung yang berada lokasi, dan dapat memecahkan kaca/gelas,

Dengan skenario seperti yang diuraikan terhadap kedua SPPBE tersebut, maka efek ledakan yang terjadi diperlihatkan pada Tabel 2.

Tabel 2.

Hasil Analisis ALOHA

\begin{tabular}{|c|c|}
\hline SPPBE PT. BM & SPPBE PT. ISR \\
\hline - Tidak menyebabkan kerusakan bangunan & - Tidak menyebabkan kerusakan bangunan \\
\hline $\begin{array}{l}\text { - Tidak menyebabkan luka serius pada } \\
\text { pekerja/pengunjung yang berada }>19 \mathrm{~m} \\
\text { dari sumber kebocoran }\end{array}$ & $\begin{array}{l}\text { - Tidak menyebabkan luka serius pada } \\
\text { pekerja/pengunjung yang berada }>21 \mathrm{~m} \\
\text { dari sumber kebocoran }\end{array}$ \\
\hline $\begin{array}{l}\text { - Tidak memecahkan kaca bangunan yang } \\
\text { berada > } 42 \mathrm{~m} \text { dari sumber (tapak RDE } \\
\text { berada pada jarak } 2,995 \mathrm{~km} \text { dari SPPBE } \\
\text { PT. BM) }\end{array}$ & $\begin{array}{l}\text { - Tidak memecahkan kaca bangunan yang } \\
\text { berada > } 44 \mathrm{~m} \text { dari sumber (tapak RDE } \\
\text { berada pada jarak } 4,141 \mathrm{~km} \text { dari SPPBE } \\
\text { PT. ISR) }\end{array}$ \\
\hline $\begin{array}{l}\text { Jadi dari analisis tersebut diketahui bahwa } \\
\text { ledakan yang terjadi tidak menimbulkan zona } \\
\text { bahaya yang mampu merusak bangunan, } \\
\text { kekuatan gelombang kejut dari ledakan } \\
\text { hanya mengakibatkan pekerja atau }\end{array}$ & $\begin{array}{l}\text { software MARPLOT efek ledakan dari ke } \\
\text { dua SPPBE diperlihatkan dalam Gambar } 3 \\
\text { dan Gambar 4. Dalam Gambar } 5 \text { terlihat } \\
\text { ledakan yang terjadi tidak mencapai tapak } \\
\text { sehingga tidak membahayakan tapak RDE. }\end{array}$ \\
\hline
\end{tabular}
pengunjung yang berada di sekitar sumber ledakan terluka. Dan dengan menggunakan 


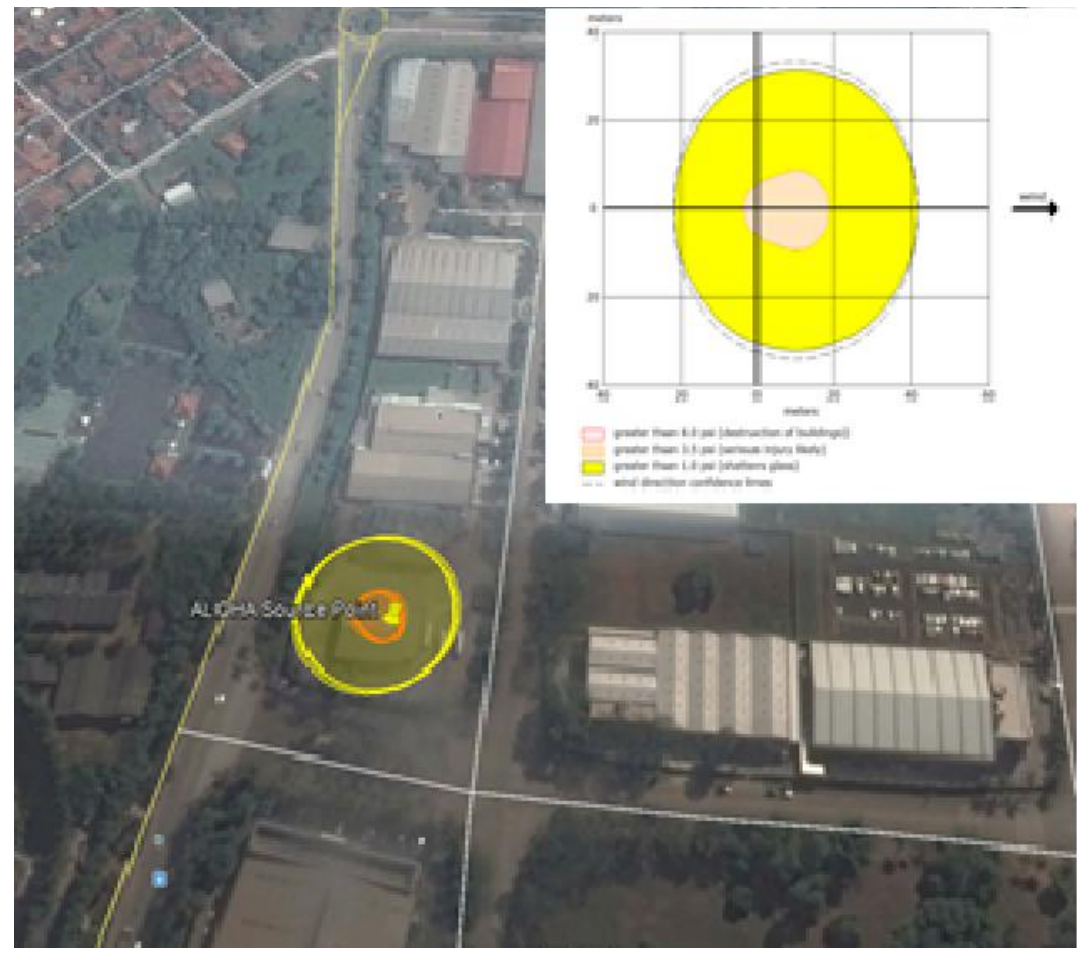

Gambar 3.

Sebaran Ledakan dari SPPBE Pt Bhakti Mingasutama

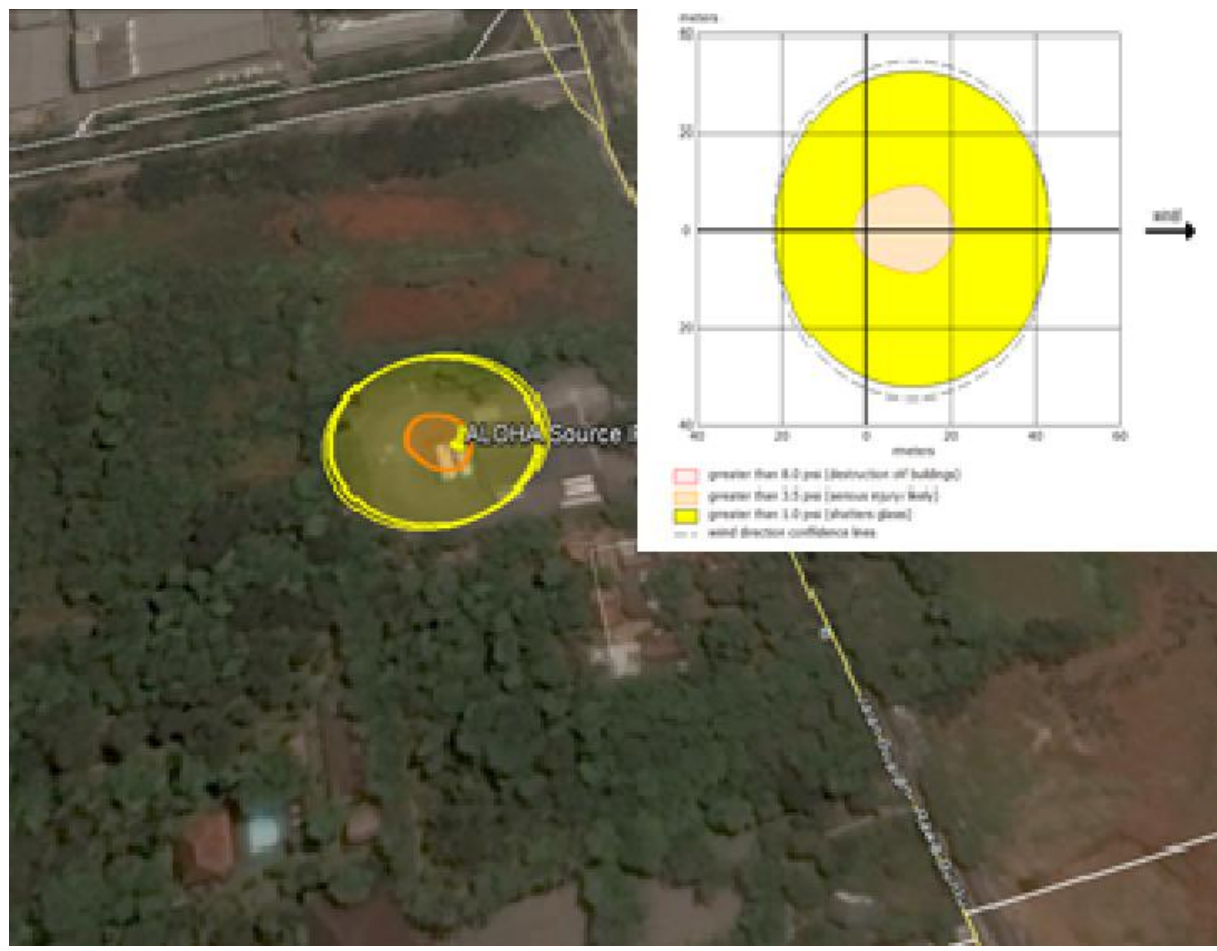

Gambar 4.

Sebaran ledakan dari sppbe PT Indah Sri Rejeki Ciater 


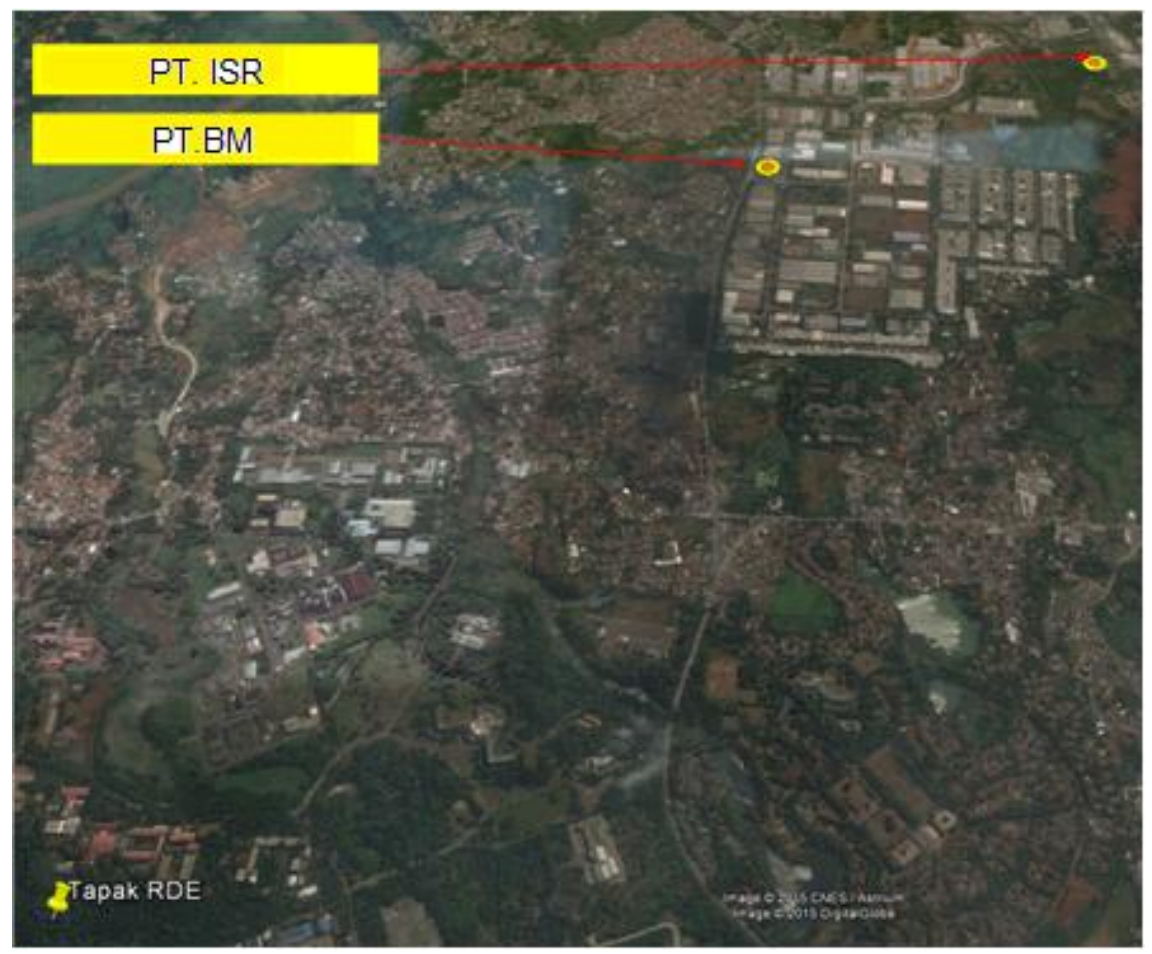

Gambar 5.

Jarak Efek Ledakan Terhadap Tapak RDE

\section{SIMPULAN}

Hasil konfirmasi di lapangan menunjukkan bahwa di sekitar area tapak hingga radius 5 $\mathrm{km}$ terdapat 2 SPPBE dengan jarak masingmasing 2,995 dan 4,141 km dari area tapak. Dengan asumsi jika terjadi kebocoran di bagian bawah tanki sebesar 2,5 inchi, menggunakan software ALOHA diketahui bahwa ledakan yang terjadi tidak menyebabkan kerusakan bangunan. Selain itu juga tidak menyebabkan luka serius pada pekerja/pengunjung yang berada $>19 \mathrm{~m}$ dari sumber kebocoran dan tidak memecahkan kaca bangunan yang berada $>42 \mathrm{~m}$ dari sumber, sehingga tidak ada potensi bahaya yang mungkin ditimbulkan oleh kegiatan SPPBE tersebut terhadap tapak RDE.

\section{UCAPAN TERIMA KASIH}

Terima kasih penulis sampaikan kepada Prof. Yulianto Sulistio Nugroho, M.Sc., Ph.D., yang telah memberikan masukan pemakaian modelling program software ALOHA untuk memperkirakan zona ancaman akibat ledakan. Juga pada Bapak Ir. Yarianto Sugeng Budi Susilo, M.Si., yang telah memberi kesempatan untuk melakukan kegiatan ini, serta pada Ir. Sriyana MT., yang telah memberikan arahan dalam penulisan makalah ini.

\section{DAFTAR PUSTAKA}

1. BAPETEN, "Evaluasi Tapak Reaktor Daya Untuk Aspek Kejadian Eksternal Akibat Ulah Manusia", Peraturan Kepala Bapeten No. 6 Tahun 2008, Jakarta 2008.

2. IAEA. NS-G-3.1 "External Human Induced Events In Site Evaluation For Nuclear Power Plants", 2002, IAEA, Vienna, 2002.

3. JUNE, MELLAWATI, YARIANTO. SBS., HADI SUNTOKO. "Sumber Potensial Bahaya Eksternal Akibat Manusia Pada Survei Tapak PLTN" Jurnal Pengembangan Energi Nuklir. Vol. 12. No.1, Juni 2010. Hal 28-37.

4. AFROX, "Material Safety Data Sheet (MSDS)", Ref. No. : MS111, Version 2, March, 2014.

5. ISHAK, MSB., "Determination of Explosion Parameter of LPG-Air Mixtures in The Closed Vessel", a Thesis Submitted In Fullfillment Of The Requirements for The Award of The Degree of Bachelor of Chemical Engineering, Nov., 2008. 
6. THE ENGINEERING TOOLBOX, Propane Butane Mix- Evaporation Pressure,

www.engineeringtoolboc.com/propanebutane-mix-d_1043.html, diakses Januari, 2016.

7. DIAN SARTIKA K., Analisis Konsekuensi Dispersi Gas, Kebakaran dan Ledakan Akibat Kebocoran Tabung LPG $12 \mathrm{Kg}$ di Kelurahan Manggarai Selatan Tahun 2012 dengan Menggunakan Breeze Incident Analyst Software", Skripsi Fakultas Kesehatan Masyarakat, UI,Jakarta, Juni, 2012.

8. A CORPORATION DEVOTED TO ENERGY-ORIENTED NEEDS, "Technical Data for Propane, Butane, and EPG Mixtures", Alternate Energy Systems, Inc, USA, January, 2016.

9. AFROX, "Luquefied Petroleum Gas", Product Referenve Manual Section 5, January, 2016.
10. IKE PUJIRIANI, "Analisis Potensi Risiko Keselamatan Liquefied Petroleum Gas (LPG) Di Depok Tahun 2011", Tesis Fakultas Kesehatan Masyarakat, Program Studi Magister Keselamatan dan Kesehatan Kerja, UI, Januari 2012.

11. SPYROS SKLAVOUNOS, et. all., Estimation of Safety Distances in the Vicinity of Fuel Gas Pipelines", Journal of Loss Prevention In The Process Industries, Vol. 19, Jan. 2006.

12. BJERKETVEDT, D., ET.ALL, "Gas Explosion Handbook", Journal of Hazardous Material , 52, 1997.

13. BATAN, "Kejadian Eksternal Akibat Ulah Manusia", Laporan Evaluasi Tapak rev. 0, 2015, PKSEN, BATAN, Jakarta

14. US.ENVIROMENTAL PROTECTION AGENCY, "User's Manual ALOHA", The Cameo Software System, National Oceanic and Atmospheric Administration, February 2007. 